\title{
DÜBLIN
}

Technological University Dublin

ARROW@TU Dublin

\section{Who Do Work Placements as Part of an Undergraduate Degree Programme Benefit?}

\author{
Jacinta E. Browne \\ Technological University Dublin, jacinta.browne@tudublin.ie \\ David O'Brien \\ Technological University Dublin, david.obrien@tudublin.ie \\ John Dorna \\ Technological University Dublin
}

Follow this and additional works at: https://arrow.tudublin.ie/scschphyot

Part of the Physics Commons

\section{Recommended Citation}

Browne, Jacinta E.; O'Brien, David; and Dorna, John, "Who Do Work Placements as Part of an Undergraduate Degree Programme Benefit?" (2012). Other Resources. 1.

https://arrow.tudublin.ie/scschphyot/1

This Other is brought to you for free and open access by the School of Physics \& Clinical \& Optometric Science at ARROW@TU Dublin. It has been accepted for inclusion in Other Resources by an authorized administrator of ARROW@TU Dublin. For more information, please contact arrow.admin@tudublin.ie, aisling.coyne@tudublin.ie, gerard.connolly@tudublin.ie.

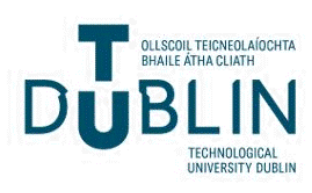


Who do work placements as part of an undergraduate degree programme benefit?

JE Browne, D O’Brien, J Doran

School of Physics, Dublin Institute of Technology, Kevin Street, Dublin 8

It has been reported by the Higher Education Academy Physical Science Centre in the United Kingdom that work/industrial placements which are integrated as closely as possible with a degree programme and which incorporate all the day-to-day pressure of the work culture represents the best practice in work experience that can be offered to students. The School of Physics of the Dublin Institute of Technology offer an Honours Degree Physics "Physics with Medical Physics and Bioengineering" which has specialisation in the areas of medical physics, bioengineering and medical devices; this degree programme has in year 3 an eight month work / industrial placement. This type of industrial placement in the School of Physics of the Dublin Institute of Technology is in its fourth year and it is clear from the performance of the students when entering into their final year that this endeavour is hugely beneficial to them. The nature of the work carried out by these students while on placement can vary widely but usually involves some of the following:

(1) The student may undertake a traditional independent project on an area of research relevant to the company;

(2) The students carry out basic routine work under the supervision of staff;

(3) The students are involved in the development of new procedures or review of current procedure by referencing current best practice in the area.

However, it has also become evident that the student is not the only beneficiary in this set-up, the company or organisation where the student was based for their placement also benefits and some of the outcomes for the host organisation to date have been:

(1) Scientific presentations at International Conferences

(2) Scientific publications

(3) Patents

(4) Audits of current practices

(5) Development of new procedures within the department

In this poster the main outcomes from work / industrial placement will be presented in the form of case studies. 